\title{
INTERAKSI SOSIAL ANTARA WARGA PERMUKIMAN REAL ESTAT DENGAN PENDUDUK DI SEKITAR NYA
}

\author{
Parino Rahardjo ${ }^{1}$, Softy Nuzzela ${ }^{2}$ \\ ${ }^{1}$ Program Studi Perencanaan Kota dan Real Estat, Universitas Tarumanagara \\ Email: parinor@ft.untar.ac.id \\ ${ }^{2}$ Program Studi Perencanaan Kota dan Real Estat, Universitas Tarumanagara \\ Email:Snuzzela@gmail.com
}

Masuk : 18-08-2020, revisi: 01-09-2021, diterima untuk diterbitkan :02-09-2021

\begin{abstract}
ABSTRAK
Permukiman Bonana, berlokasi di Kecamatan Cilandak, kelurahan Lebak Bulus. Dibangun pada lahan seluas 38 Ha, merupakan hasil konversi kebun dan rawa milik penduduk yang saat ini sebagian masih mendiami perkampungan di sekitar Permukiman tersebut. Pada umumnya mereka yang bekerja di Permukiman Bonana, bertempat tinggal di perkampungan disekitar permukiman Bonana. Permukiman Bonana dilengkapi dengan fasilitas umum dan sosial. Permukiman Bonana di lengkapi dengan Ruang Terbuka Hijau, berupa taman, lapangan tenis, dan ruang terbuka hijau sepanjang saluran utama drainase. Ruang terbuka hijau yang dilengkapi dengan tempat permainan anak (playground), lapangan basket dan bulu tangkis dan fasilitas peribadatan masjid. Sarana yang ada di dalam Permukiman Bonana dimanfaatkan juga oleh warga sekitar Permukiman Bonana. Di dalam Permukiman, fasilitas ekonomi formal yang dibangun oleh pengembang berupa pertokoan dengan fasilitas perbankan, kebutuhan rumah tangga, kebutuhan medis, dan tempat makan, di samping itu terdapa terdapat pasar informal yang menjual kebutuhan sehari-hari. Pasar informal ini dibentuk oleh masyarakat pedagang. Pada umumnya permukiman yang dibangun oleh pengembang umumnya tertutup terhadap masyrakat sekitarnya, sebagai tidakan preventif terhadap tindak kriminal, namun Permukiman Bonana terbuka antara warga permukiman dengan masyarakat sekitar. Tujuan penelitian mengetahui bentuk partisipasi warga Permukiman Bonana untuk menjaga keamanan dan kenyamanan permukimannya. Penelitian menggunakan pendekatan kualitatif dengan pengumpulan data dengan wawancara dan observasi, dan dengan menggunakan narasumber. Penelitian mendapatkan partisipasi warga Permukiman Bonana untuk menjadikan permukiman yang aman dan nyaman.
\end{abstract}

Kata Kunci: Masyarakat; Interaksi Sosial; Ruang Terbuka Hijau; Ruang Terbuka Publik

\begin{abstract}
The Bonana settlement is located in Cilandak sub-district, Lebak Bulus village. Built on an area of 38 hectares, it is the result of the conversion of gardens and swamps owned by residents who currently still live in the villages around the settlement. In general, those who work in the Bonana Settlement, live in the villages around the Bonana settlement. The Bonana settlement is equipped with public and social facilities. The Bonana settlement is equipped with green open spaces, in the form of gardens, tennis courts, and green open spaces along the main drainage channel. Green open space equipped with a children's play area (playground), basketball and badminton courts and mosque worship facilities. The facilities in the Bonana Settlement are also used by residents around the Bonana Settlement. Within the Settlement, the formal economic facilities built by the developer are shops with banking facilities, household needs, medical needs, and places to eat, in addition there is an informal market that sells daily necessities. This informal market was formed by the trading community. In general, settlements built by developers are generally closed to the surrounding community, as a preventive measure against crime, but the Bonana Settlement is open between residents of the settlement and the surrounding community. The purpose of the study was to determine the form of participation of the residents of the Bonana Settlement to maintain the security and comfort of their settlements. The study used a qualitative approach with data collection by interviews and observations, and by using sources. The study obtained the participation of residents of the Bonana Settlement to make a safe and comfortable settlement.
\end{abstract}

Keywords: Community; Social Interaction; Green Open Space; Public Open Space 


\section{PENDAHULUAN}

Pengembangan Kebayoran Baru, dilakukan oleh pemerintah, dan pada tahun 1970an sektor swasta yang dimotori pengusaha Ciputra melihat adanya peluang pasar membangun kawasan permukiman elit untuk masyarakat berpenghasilan tinggi di sebelah selatan Kebayoran Baru. Pengembangan permukiman yang mengonversi kampung penduduk Pondok Pinang, dan perkebunan. Penamaan Pondok Indah untuk mengingat desa Pondok Pinang, kawasan di mana pengembangan permukiman ini dilakukan.

Pembangunan Permukiman Pondok Indah, mendorong pengembangan permukiman-permukiman lain untuk kelompok sosial menengah atas yang dikembangkan di sebelah selatan Pondok Indah. Salah satunya adalah Permukiman Taman Bonana. Permukiman yang dibangun dengan lahan seluas $38 \mathrm{Ha}$, merupakan hasil koneversi kebun dan rawa milik penduduk. Penduduk lokal saat ini sebagian masih mendiami perkampungan di sekitar permukiman tersebut. Pada umumnya mereka yang bekerja di Permukiman Bonana, bertempat tinggal di perkampungan di sekitar permukiman tersebut. Permukiman Bonana dilengkapi dengan pertokoan yang dibangun oleh pengembang yang menjual kebutuhan warga permukiman maupun penduduk sekitarnya, di dalam permukiman terdapat juga pasar kaget yang menjual sayur dan kebutuhan hidup sehari-hari bagi warga Permukiman Bonana maupun warga sekitarnya. Tempat berjualan ini dikreasikan oleh masyarakat dengan memanfaatkan akses keluar/masuk Permukiman Bonana yang tidak lagi digunakan.

Permukiman Bonana di lengkapi dengan Ruang Terbuka Hijau berupa taman, lapangan tenis, dan ruang terbuka hijau sepanjang saluran utama drainase. Ruang terbuka hijau yang dilengkapi dengan tempat permainan anak (playground), lapangan basket dan bulu tangkis dan fasilitas peribadatan masjid. Sarana yang ada di dalam Permukiman Bonana dimanfaatkan juga oleh warga sekitar Permukiman Bonana.

\section{Lingkungan Buatan}

"Ekologi lanskap menekankan skala spasial yang luas dan dampak ekologi dari pola spasial ekosistem mencakup (a) perkembangan dan dinamika heterogenitas spasial, (b) interaksi dan pertukaran di seluruh lanskap heterogen, (c) pengaruh spasial heterogenitas pada proses biotik dan abiotik, dan (d) manajemen heterogenitas spasial (Turner, 1989). Menurut Moss (1999), "Ekologi lanskap untuk mendapatkan pemahaman tentang lanskap dan meningkatkan kemampuan mengelola lebih efektif untuk mengatasi berbagai macam masalah lingkungan (Antrop, 2000)." Pengembangan sebuah permukiman, yang mengonversi ladang/pertanian maupun perkampungan menyebabkan terjadinya perubahan lanskap, area vegetasi berubah menjadi lingkungan yang kedap air, sehingga kapasitas infiltrasi menjadi berkurang dan mengakibatkan terjadinya limpasan air. Struktur lanskap untuk memenuhi dan mendukung aktivitas warga maupun untuk menjaga kualitas lingkungan, antara lain: (1)Patch berupa ruang terbuka hijau berupa taman-taman, lapangan olahraga, (2)Koridor berupa jaringan infrastruktur, dan penghubung, saluran air dan sungai, (3)Matriks merupakan area terbangun kumpulan gedung-gedung merupakan elemen yang homogen dan dominan. Ruang terbuka hijau, koridor hijau terbangun, memelihara siklus hidrologi, mengurangi temperatur udara mikro dan melindungi keberadaan spesies yang ada di dalamnya termasuk manusia. (Rao, 1997). Melalui ruang terbuka hijau, orang-orang berhubungan dengan alam. Ruang hijau kota melayani banyak peran ekologis, dan dapat dirancang dan dikelola. Ruang terbuka hijau dapat membersihkan dan mengembalikan air bawah tanah, dengan menampung air hujan. Ruang terbuka hijau dapat mengurangi pulau panas perkotaan dan dapat mengurangi panas atau mendinginkan bangunan. Ruang Terbuka Hijau juga sebagai penyedia habitat untuk satwa liar (Cynthia Girling and Ronald Kellett, 2005). 
Empat faktor sangat efektif untuk utilitas ruang, faktor (1)Pertama adalah kontinuitas ruang dan akses mudah terhadapnya, faktor (2)Kedua menunjukkan aktivitas orang-orang di ruang ini. Faktor (3)Ketiga mengacu pada kenyamanan dan daya tarik ruang tersebut. Faktor (4)Keempat yaitu tempat sosial yang memungkinkan interaksi sosial bagi masyarakat (Mamaghania, Asadollahib, Mortezaei, 2015). Sebuah wilayah secara luas sebagai 'tempat dimana orang tinggal pekerjaan sehari-hari dan kehidupan rumah tangga mereka, dan, lebih spesifik, sebagai basis potensial dari mana 'subjek dapat menjalankan kapasitas mereka untuk proaktif dengan efektif intervensi individu dan kolektif di dalam dan di luar basis itu. Kita memiliki dasar rasa 'memiliki' pada suatu wilayah tertentu atau ruang yang, dipahami dengan beragam sebagai area, permukiman, permukiman atau skema (Robertson, Smyth and McIntosh, 2008). Untuk sebagian besar, sumber daya permukiman terbatas pada penyediaan tempat tinggal dan komoditas penting bagi penduduk. "Kombinasi permukiman dan belanja mendukung kehidupan dan dalam prosesnya meletakkan pola aktivitas sosial yang menjadi bagian penting kehidupan masyarakat (Rivlin dalam, Altman \& Wandersman, 1987)." Menurut Unger dan Wanderdman (1985), permukiman merupakan bagian dari sosial, emosional, dan pengalaman kognitif anak (Rivlin dalam, Altman \& Wandersman, 1987), pendapat ini didukung oleh Girling, Kellett, (2005), bahwa densitas cukup tinggi dan penggunaan lahan campuran meningkatkan kemungkinan bahwa layanan sehari-hari (toko, rekreasi, dan sekolah, misalnya) berada pada jarak berjalan kaki. Interaksi sosial pada sebuah permukiman dapat terjadi karena adanya fasilitas pendukung seperti Ruang Terbuka Hijau yang memiliki fungsi sosial, sebagai sebuah tempat berkumpul warga permukiman. "Penciptaan identitas tempat atau lingkungan permukiman adalah proses sosio-kultural yang kompleks dan dinamis. Identitas lokalitas mempresentasikan interaksi sosial dan faktor fisik, yang dapat didefinisikan secara eksternal. Identitas semacam itu memiliki pengaruh besar pada seberapa khusus lingkungan permukiman dipandang sebagai tempat tinggal (Robertson, Smyth and McIntosh, 2008). Lingkungan permukiman yang berbeda memiki identitas sosial yang berbeda. Dengan demikian pengembangan dan pemeliharaan suatu identitas sosial tertentu untuk lingkungan tertentu bisa jadi hasil dari upaya interaksi yang kompleks dan kekuatan internal dan eksternal (Robertson, Smyth and McIntosh, 2008)." Istilah lingkungan permukiman dan komunitas mengacu pada konsep yang berbeda, sedangkan Gottdiener dan Hutchison (2011), lingkungan permukiman didefinisikan sebagai lingkungan sosial dimana hubungan antar warga mendominasi. Karakteristik yang menentukan dari lingkungan sekitar adalah kenikmatan persahabatan di antara orang-orang yang tinggal di bagian yang sama melalui aktivitas bertetangga. Keterlibatan tetangga dan masyarakat sangat terkait dengan siklus hidup - apakah individu itu lajang atau sudah menikah, tanpa anak atau dengan anak-anak. Sebagian besar tetangga cenderung dilakukan oleh orang-orang yang membesarkan keluarga (Gottdiener, Hutchison, 2011).

Masyarakat atau warga permukiman mempunyai sistim sosial yang mereka bangun tanpa adanya rekayasa atau desain, tetapi terbentuk karena adanya kebutuhan diantara warga, dalam kerangka sistim sosial, unsur yang mendukungnya adalah interaksi sosial. Diferensiasi antara dukungan sosial dan jejaring sosial memberikan pemahaman tentang isi dan jenis interaksi sosial yang berkembang antar tetangganya. Dukungan sosial terutama mengacu pada frekuensi interaksi antar penduduk. Dukungan pribadi (emosional) mengurangi isolasi sosial dan meningkatkan kepemilikan sosial (Homoud \&Tassinary, 2004), "Manusia dikatakan sebagai makhluk sosial, karena beberapa alasan, yaitu: a) Manusia tunduk pada aturan, norma sosial, (b) Perilaku manusia mengharapkan suatu penilaian dari orang lain, (c) Manusia memiliki kebutuhan untuk berinteraksi dengan orang lain, (d) Potensi manusia akan berkembang bila ia hidup di tengah-tengah manusia (Park dan Burgess 1921)". Interaksi sosial dipengaruhi oleh lingkungan sosial, seperti klas sosial, dan menurut Sally Engle Merry (1987), lingkungan pribadi ini ditandai dengan penggunaan ruang, 
privasi, dan sarana formal kontrol sosial untuk mengelola masalah kedekatan. Rasa memiliki berasal dari identitas sosial yang stabil dari pada bertahan dalam hubungan sosial, dalam Altman \& Wandersman, Edit, (1987). Kemiskinan bisa dianggap sebagai masalah perkotaan karena konsentrasinya besar pada lingkungan permukiman kota, seperti yang ditunjukkan perspektif socio spatial (Gottdiener, Hutchison.,2011)." Konsep "kriminalitas" mengacu pada kecenderungan orang melakukan tindak pidana. Kecenderungan ini dapat ditentukan dengan bantuan karakteristik tindak pidana. Menurut Gottfredson dan Hirschi, tindakan kriminal menjanjikan keuntungan segera atau kepuasan kebutuhan yang mudah, sangat menarik, hanya memiliki sedikit keuntungan jangka panjang, memerlukan keterampilan atau perencanaan yang rendah, dan seringkali menimbulkan rasa sakit dan masalah bagi para korban. definisi kejahatan sebagai pelanggaran. Hal ini memungkinkan mereka untuk menentukan sifat kriminal (Siegmunt. O, 2016).

"Permukiman eksklusif era tahun 1980an dan 1990an dengan dengan menggunakan petugas keamanan dan penghalang. Tempat dengan pengaturan ini, di mana pengunjung dan penduduk harus berhenti di pos keamanan untuk mendapatkan akses, dikenal sebagai gated communities (Gottdiener, Hutchison.,2011).”. Menurut Sanchez, Lang, and Dhavale (2005). permukiman model gated community, faktor yang mendasarinya adalah keamanan (Gottdiener, Hutchison.,2011).”

\section{Rumusan Masalah dan Tujuan Penelitian}

Pada umumnya permukiman yang dibangun oleh pengembang umumnya tertutup terhadap masyrakat sekitarnya, sebagai tidakan preventif terhadap tindak kriminal. Permukiman Bonana terbuka, dapat diakses oleh masyarakat sekitar. Pengembangan sebuah permukiman idealnya adalah, sebuah permukiman yang dapat di akses oleh warga sekitarnya, artinya fasilitas publik yang ada di dalamnya dapat dimanfaatkan oleh penduduk sekitarnya, yang memungkin dapat berinteraksi secara sosial dengan warga disekitar permukiman tersebut. Idealnya warga berpatisipasi terhadap keamanan dan kenyamanan permukimannya berupa membiayai keamanan maupun kebersihan, dan ikut memikirkan bentuk pengamanan maupun keindahan permukiman.

Tujuan penelitian mengetahui partisipasi masyarakat untuk menjaga kenyamanan dan keamanan permukiman, dan mengetahui interaksi sosial antara warga permukiman real estat dengan penduduk di sekitar permukiman. Penelitian menggunakan pendekatan kualitatif, dengan melakukan interpretasi dan analisis data dengan metode deskriptif.

\section{METODE PENELITIAN}

\section{Lokasi Penelitian}

Penelitian di lakukan pada Permukiman Bonana, yang berada pada Kelurahan Lebak Bulus, Kecamatan Cilandak, Kota Jakarta Selatan. Waktu Penelitian dimulai pada bulan November 2018 sampai dengan Desember 2019. secara geografis lokasinya berada antara $06^{\circ} 17^{\prime} 30^{\prime \prime}$ dan $06^{\circ} 18^{\prime} 00^{\prime}$ Lintang Selatan dan 106 46’30” dan 10647’00” Bujur Timur. 


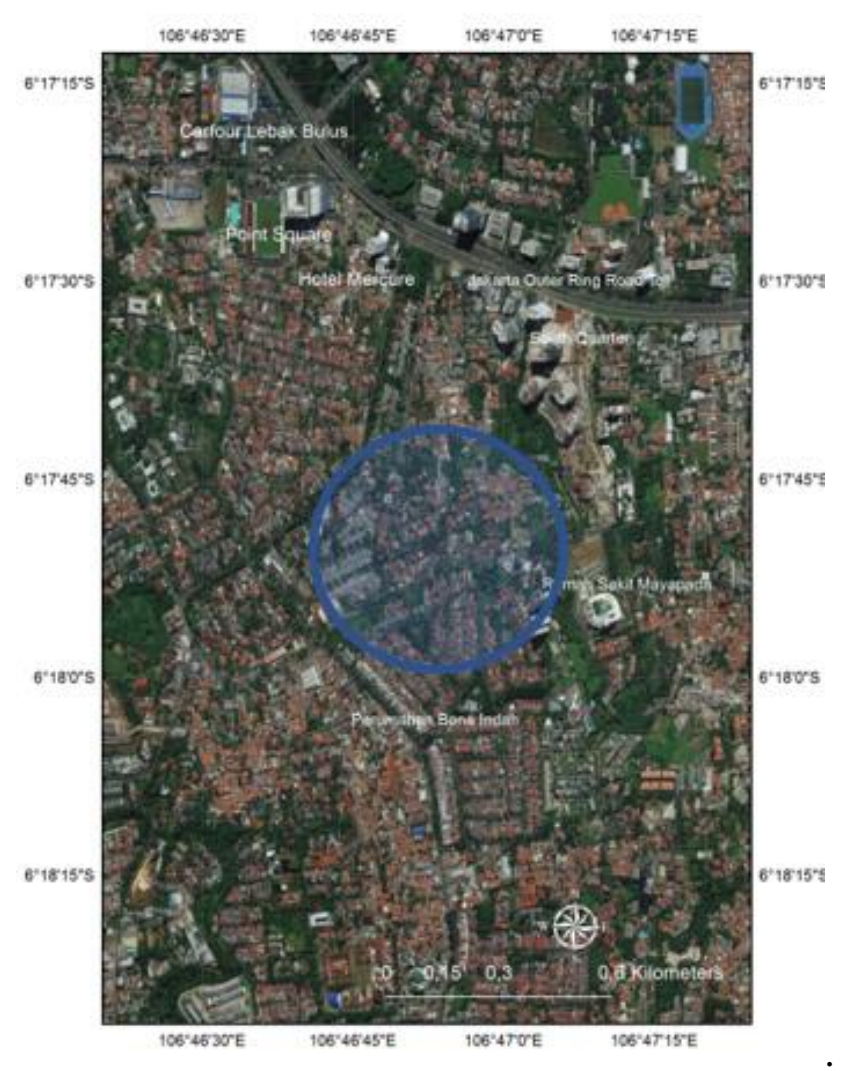

Gambar 1. Lokasi Penelitian

Sumber: ArcGis 10.2

Penelitian menekankan pada interpretasi subyektif, untuk mengkaji pandangan warga dan masyarakat luar permukiman terhadap permukiman Bonana. Pendekatan pada penlitian ini menggunakan pendekatan kualititif, dengan observasi lapangan untuk pengumpulan data, berlandasan metode Purposive Sampling untuk mengamati fenomena yang ada pada obyek penelitian, dan wawancara untuk mendapatkan data pandangan warga Bonana dan warga diluarnya mengenai permukiman Bonana.

Penelitian mengkatagorikan obeyek penelitian pada hal, lingkungan terbangun, dan lingkungan sosial. Pengumpulan dengan Teknik Observasi di lakukan pada lingkungan terbangun dengan menggunakan Teori Ekologi Lanskap untuk mendapatkan data antara lain: Ruang Terbuka Hijau, Vegetasi, dan Fasilitas Pendukung, seperti area pertokoaan dan mengkaji kenyamanan area permukiman, sedangkan wawancara, untuk mendapatkan pandangan dan partisipasi warga, menggunakan Teori Sistim Sosial digunakan untuk mengkaji interaksi sosial antara warga permukiman, dengan warga diluar permukiman.

Pengumpulan data menggunakan metode wawancara mendalam menggunakan nara sumber yaitu pengurus Rukun Warga, Satpam, Tokoh masyarakat dan Pedagang yang berjualan, Analisis data menggunakan metode deskriptif dan interpretasi. Ketua dan pengurus RW, serta Tokoh Masyarakat, menjelaskan aktifitas dan partisipasi warga, meliputi: Keamanan, Kebersihan, Pemberantasan sarang nyamuk, bazar, olah raga.

Pedagang yang berjualan di dalam permukian menjelaskan mengenai sikap warga permukiman dan warga sekitarnya dalam melakukan transaksi, dan tanggungan jawab pedagang terhadap kebersihan dan keamanan di dalam Permukiman. Warga luar permukiman menjelaskan aktivitas mereka dan interaksi mereka di ruang publik di dalam permukiman dengan warga permukiman. 
Pengumpulan data dengan melakukan observasi dilakukan untuk mengetahui fenomena fisik lingkuangan buatan yang ada di dalam permukiman, seperti kondisi perumahan, Ruang Terbuka Hijau, drainase, jalan, lapangan olah raga dan ply ground. Hasil wawancara dan obervasi di seleksi, untuk memisahkan data yang tidak relevan dengan penelitian, kemudian data dianalisis dengan interpretasi dan diskriptif, di bandingkan dengan teori yang ada.

\section{Hasil Dan Pembahasan Penelitian}

Lingkungan hidup permukiman Bonana dapat dikatakan sebagai sebuah ruang yang dibagi dalam 3, klasifikasi, yaitu Lingkungan Alami, Lingkungan Sosial, dan Lingkungan Terbangun, Lingkungan Alami berupa sungai yang berada Sisi Timur, Lingkungan Buatan berupa bangunan rumah, lapangan olah raga, jalan, dan drainase, ruang terbuka hijau, sedangkan Lingkungan Sosial, dan Ekonomi berupa ruang Terbuka Publik, Masjid, Lapangan Olah Raga, dan Ply Ground. Permukiman merupakan sebuah lingkungan hidup yang pada undang-undang no 32/2009 tentang perlidungan dan pengelolaan lingkungan hidup, diartikan sebagai "Kesatuan ruang dengan semua benda, daya, keadaan, dan makhluk hidup, termasuk manusia dan perilakunya, yang mempengaruhi alam itu sendiri, kelangsungan peri kehidupannya, dan kesejahteraan manusia serta makhluk hidup lain (Pasal 1, ayat 1)." Sebagai entitas sosiologis, lingkungan dibedakan dari kawasan pemukiman berdasarkan derajat organisasi sosial di antara penghuninya. Berbeda dengan lingkungan, kawasan pemukiman memiliki sedikit atau tidak ada hubungan yang terpola di antara penghuninya. Kawasan pemukiman dapat menjadi lingkungan dan sebaliknya tergantung pada kelangsungan hidup dan luasnya jaringan hubungan sosial antar warga (Schwirian,1983)."

Seperti istilahnya, komunitas yang terjaga keamanannya (gated communities) mendirikan gerbang utama untuk penduduk atau pengunjung; mereka juga membatasi titik masuk; membangun tembok dan pagar keliling; dan mempekerjakan penjaga keamanan swasta, kamera pengintai, dan detektor gerakan inframerah (William G. Flanagan. G.W. 2010).

\section{Lingkungan Buatan/Fisik}

Lahan Permukiman Bonana hampir seluruhnya terbangun, pada beberapa blok menyisakan lahan kosong (belum terbangun). Jumlah rumah yang terbagun antara lain:

Tabel 1. Blok permukiman dan Jumlah Rumah

Sumber: Rencana Tapak Perumahan Bonana (1986), dan Observasi selama penelitian

\begin{tabular}{cc}
\hline Blok Permukiman & Jumlah rumah \\
\hline Blok A & 28 \\
A1 & 36 \\
A2 & 65 \\
A3 & 55 \\
A4 & 18 \\
A5 & 52 \\
A6 & 47 \\
A7 & 24 \\
A8 & 37 \\
A9
\end{tabular}




\begin{tabular}{cc}
\hline Blok B & 37 \\
B1 & 28 \\
B2 & 29 \\
B3 & 53 \\
B4 & 19 \\
B5 & 27 \\
B6 & 30 \\
B7 & 35 \\
B8 & 23 \\
\hline Blok C & 25 \\
C1 & 11 \\
C2 & 14 \\
C3 & \\
C4 & \\
\hline Jumlah Rumah 658 Rumah Tinggal \\
\hline
\end{tabular}

Dari sisi keamanan, Permukiman Bonana mendapat keuntungan dengan dengan ditempatkannya Pos Polisi, Polsek Cilandak, di RW 06, yang kantornya bersebelahan dengan kantor RW.

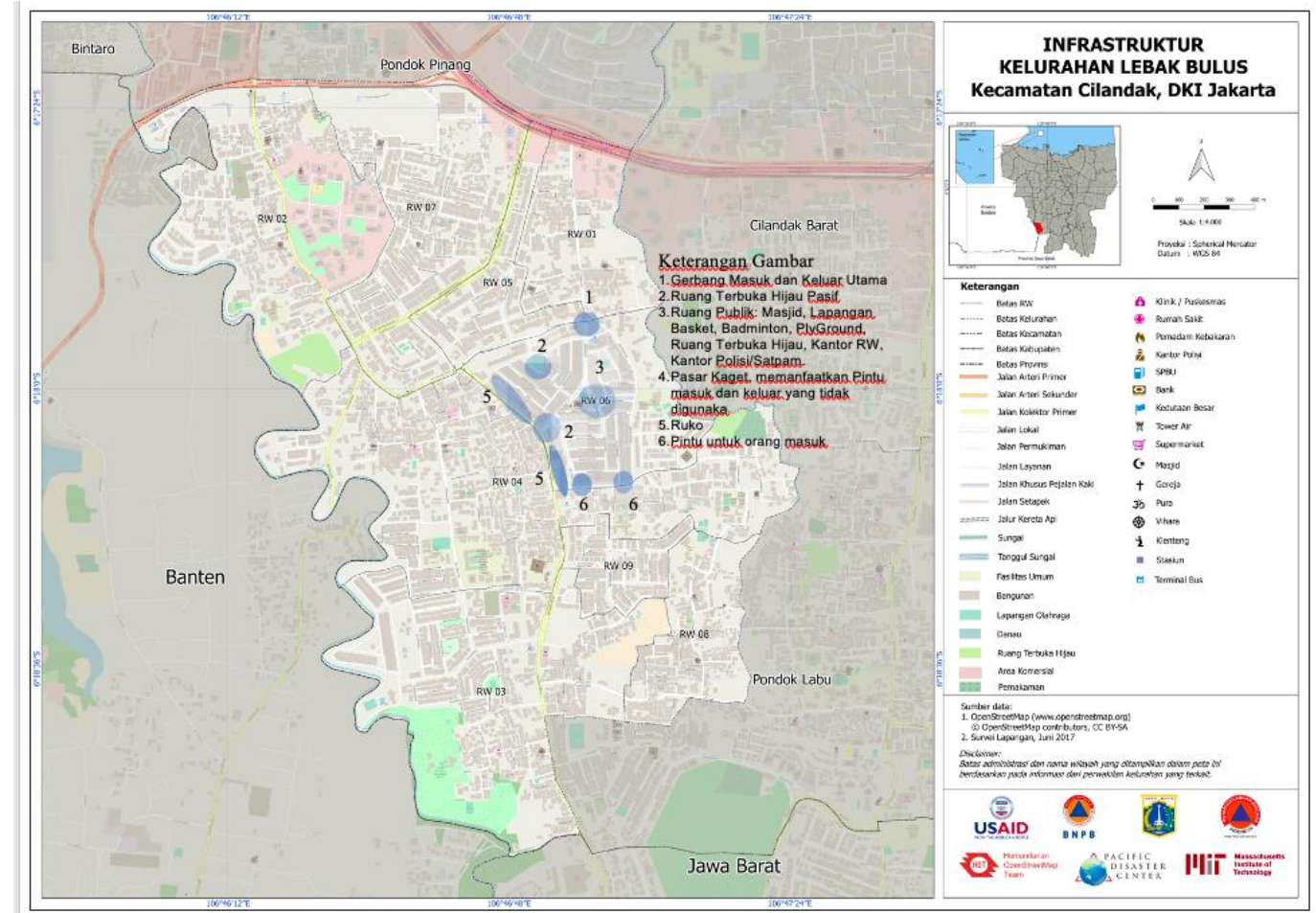

Gambar 2. Ruang Terbuka, Fasilitas Publik, dan Pintu Masuk Sumber: https://drive.google.com/file/d/10CuWrvcrGM_IGKTKTP5GbpkgEuRKaB

\section{Ruang Publik}

Ruang Terbuka Hijau Publik, dengan fasilitas lapangan basket dan Badminton tempat bermain anak, dimanfaatkan oleh warga Permukiman Bonana maupun warga di luar Permukiman Bonana. 
Ruang terbuka hijau di Permukiman Bonana merupakan sebuah ruang terbuka yang memiliki fungsi menjaga keseimbangan lingkungan perkotaan. Ruang terbuka hijau adalah area memanjang/jalur dan/atau mengelompok, yang penggunaannya lebih bersifat terbuka, tempat tumbuh tanaman, baik yang tumbuh secara alamiah maupun yang sengaja ditanam (Pasal 1). Kemudian pada Pasal 29, Ruang Terbuka Hijau (RTH) dapat berupa ruang publik dan ruang privat (1), keluasan RTH pada wilayah kota paling sedikit $30 \%$ dari luas wilayah kota (2), proporsi ruang terbuka hijau publik pada wilayah kota paling sedikit $20 \%$ dan $10 \%$ privat dari luas wilayah kota. Keberadaan RTH diperjelas kembali pada permen PU No: 05/PRT/M/2008 tentang pedoman penyediaan dan pemanfaatan RTH di kawasan perkotaan. Ketentuan 30\% luas RTH merupakan besaran minimal. Letak ruang terbuka hijau pada Permukiman Bonana terpusat atau tersebar di beberapa lokasi. Sebagai upaya untuk menjaga keseimbangan lingkungan. RTH memiliki fungsi, ekologis, sosial budaya, estetika, dan ekonomi. Keberadaan pohon sebagai elemen kota, berkontribusi sangat besar terhadap kualitas lingkungan perkotaan, banyak jasa yang dapat diberikan oleh pohon. Menurut Rode dan Burdett (2011), "Pohon mengurangi efek buruk dengan mengurangi dan meredam stormwater, yang ditahan oleh daun, cabang dan batang, atau dapat kembali ke atmosfer melalui penguapan, pengaturan aliran air dan kualitas udara untuk peneduh, tempat tinggal dan tempat mencari makan, serta area berkembang biak satwa liar. Menurut Zabel (2007), dan Soeriaatmadja (1989), "pohon dapat mengendalikan pencemaran udara akibat gas buang (emisi), sehingga mengurangi serta menghilangkan polutan." Vegetasi memiliki pengaruh terhadap pengurangan polusi. Pohon di dalam Permukiman Bonana, pada Ruang Terbuka Hijau Pasif dan aktif, atau pada sepanjang jalan di dalam Permukiman, dan drainase.
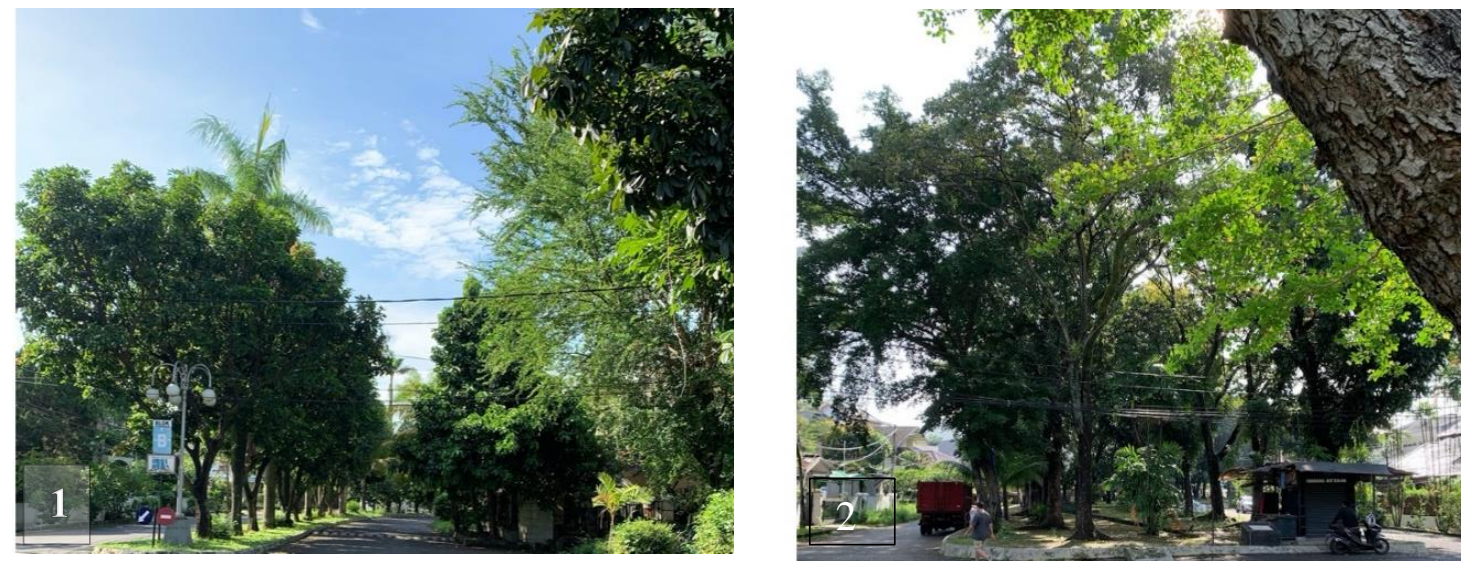

Gambar 3. Pohon di Jalan dan Saluran Air

Keterangan 1: Pohon di Jalan, 2 Pohon di Saluran Air.

Ruang terbuka Hijau di dalam permukiman Bonana, berupa Ruang Terbuka Hijau Publik dengan fasilitas lapangan olah raga, seperti lapangan Basket, dan Lapangan Badminton serta fasilitas untuk permainan anak (Children Play Ground) yang dapat dinikmati oleh masyarakat di luar Permukiman Bonana, merupakan tempat Interaksi antara sesama warga dan masyarakat di luar Bonana. Pembangunan perkotaan menutup lahan 40 persen hingga 95 persen dengan atap dan paving, menjadikan permukaan kedap air. Konversi lanskap yang luas mempengaruhi hidrologi lokal (Cynthia Girling and Ronald Kellett, 2005). Untuk mengurangi dampak negatif terhadap lingkungan permukiman, seperti aliran permukaan, dan perubahan iklim mikro (Micro Climate). Penataan ruang permukiman dapat mengantisipasi akibat konversi lahan, hal yang dapat dilakukan adalah penyediaan Ruang Terbuka Hijau, maupun penanaman vegatasi di Lingkungan Permukiman. 


\section{Lingkungan Sosial}

\section{Kegiatan Ekonomi}

Kegiatan ekonomi informal berupa perdagangan yang dilakukan oleh masyarakat yang memanfaaatkan lahan yang tidak digunakan pada Permukiman Bonana, dengan demikian lokasi tempat perdagangan letaknya menyebar pada beberapa lokasi. Jumlah pedagang ini berkisar 100 pedagang dengan jumlah terbesar berada pada pintu masuk Permukiman Bonana, yang tidak difungsikan. Pedagang ini oleh pengurus RW dibebani restribusi untuk kebesihan dan keamaanan. Di samping restribusi pedagang diberi tanggung jawab untuk membersihkan lingkungan tempat mereka berjualan yang dilakukan setiap hari minggu pada minggu ketiga. Kegiatan ini dilakukan dengan cara gotong royong. Para pedangang ini mempunyai koordinator, yang berfungsi sebagai penghubung antara para pedagang dengan pihak RW.

Dari wawancara yang dilakukan, pedagang yang berjualan di dalam Permukiman Bonana pada umumnya berdagang sudah cukup lama, misalnya pak Slamet yang berprofesi sebagai pedagang Mie Pangsit sudah berjualan sejak tahun 1993, yang semula berjualan berkeliling. Berjualan di Permukiman Bonana sejak belum berkeluarga dan sekakarang sudah mempunyai seorang anak (10 tahun). Demikian juga pak Nana, pedagang Gado-gado, yang berjualan sejak tahun 2000. Jam penjualan mereka semakin pendek (cepat habis), setelah jalan TB. Simatupang menjadi pusat bisnis, dan di dalam Permukiman Bonana ada Sekolah Singapore. Hari Jumat merupakan hari tercepat saat berjualan, karena adanya Masjid. Setelah selesai sholat Jumat banyak mereka yang sholat melanjutkan makan siangnya di dalam Permukiman Bonana.

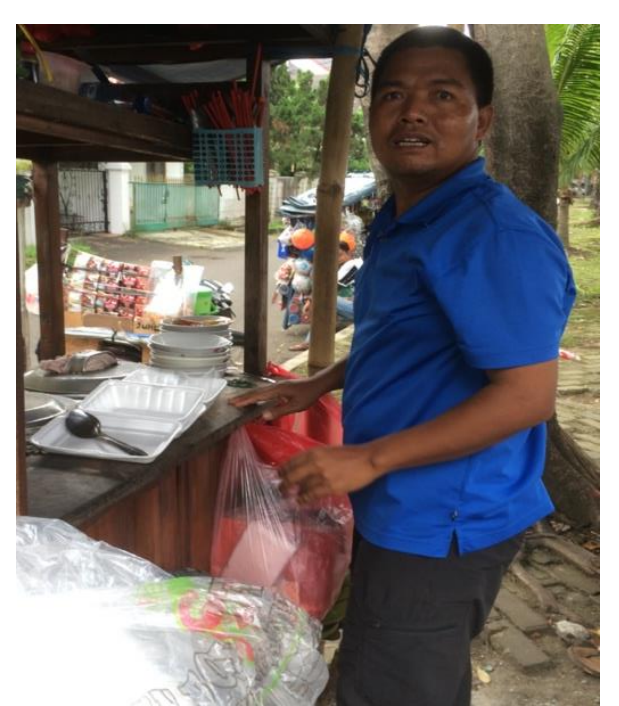

A: Pak Slamet Pedagang Mie

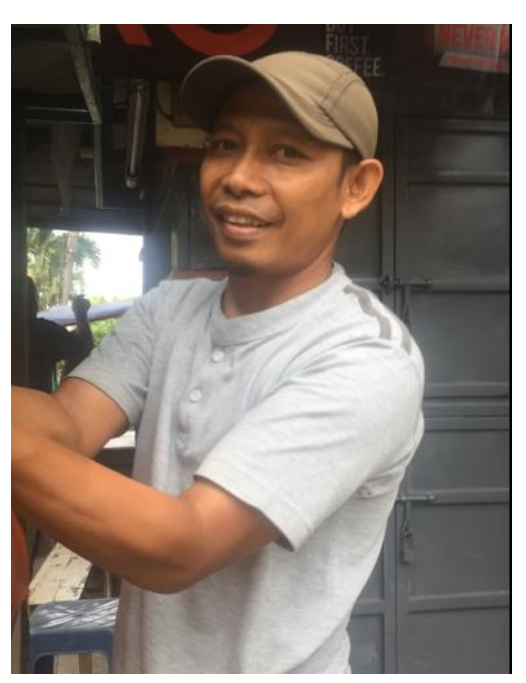

B: Pak Nana Pedagang Gado-gado

\section{Gambar 4. Profil Pedagang}

\section{Ekosistem Sosial}

Penggunaan nama ekosistem meminjam istilah yang digunakan pada ilmu lingkungan dan ekologi. Pada ekosistem melibatkan 5 unsur yanng saling terkait membentuk suatu sistem. Unsur tersebut adalah, interaksi, ketergantungan, keanekaragaman, harmoni, dan keberlanjutan. Kelima unsur ini dalam kehidupan masyarakat dapat kita jumpai, seperti (1)interaksi, yang meliputi hubungan timbal-balik antar pribadi maupun kelompok yang ada masyarakat, (2)Ketergantungan, sebagai mahluk sosial manusia tidak dapat lepas dari manusia lain, terkadang manusia harus meminta atau mendapat pertolongan dari manusia lainnya, (3)Keanekaragaman, dalam masyarakat tidak ada keseragaman, baik dari suku (ras), dari sisi ekonomi dan sosial ada manusia yang beruntung 
mendapatkan anugerah tingkat sosial menengah dan tinggi dengan harta yang cukup, bahkan berlimpah, namun ada juga manusia yang dianugerahkan keterbatasaan harta, dari ketergantungan mereka yang dianugrahi harta atau materi cukup atau berlimpah masih memerlukan bantuan dari manusia lain yang dianugerahkan harta/materi yan terbatas. Keanekaragaman ini dijumpai pada ekologi, dan semakin kaya ragam hayatinya, maka akan semakin baik ekosistem alamnya, (4)Harmoni atau keselarasan. Keanekaragaman yang kaya, bila berjalan dengan saling menghormati satu sama lain, akan mencapai harmoni (5)Keberlanjutan, merupakan hasil dari masyarakat yang harmoni, menghargai perbedaan antar manusia.

Kegiatan yang dilakukan warga Permukiman Bonana, tidak saja dilakukan oleh pengurus RW 06, tapi dilakukan juga oleh pengurus Mesjid Bonana seperti kegiatan yang terkait acara keagamaan, dan terkait dengan kesehatan, hal ini diwujudkan dengan membuka Rumah Sehat yang dimanfaatkan oleh warga dari dalam dan juga luar Permukiman Bonana yang tidak mampu. Kerja sama antara warga dengan fasilitator, merupakan wujud dari sebuah masyarakat yang baru, sebagai upaya terpeliharanya lingkungan yang nyaman dan aman di mana mereka tinggal:

Istilah "komunitas" mewakili sekelompok orang yang berakar dalam suatu tempat dengan hubungan timbal balik dan saling percaya satu sama lain dan lanskap mereka. Dengan demikian, komunitas bukan hanya tempat statis dalam lanskap statis, tetapi lebih hidup, resonansi diri yang memperkuat sistem hubungan yang selalu berubah, interaktif, interdependen. Karena komunitas adalah sistem pengaturan diri dalam sistem lingkungan yang lebih besar, ia tidak hanya memasukkan informasi tetapi juga mengubah lingkungannya. Jadi, komunitas dalam kehidupannya mengubah lanskap, maka lanskap dalam reaksi mengubah komunitas (Flint, 2013).
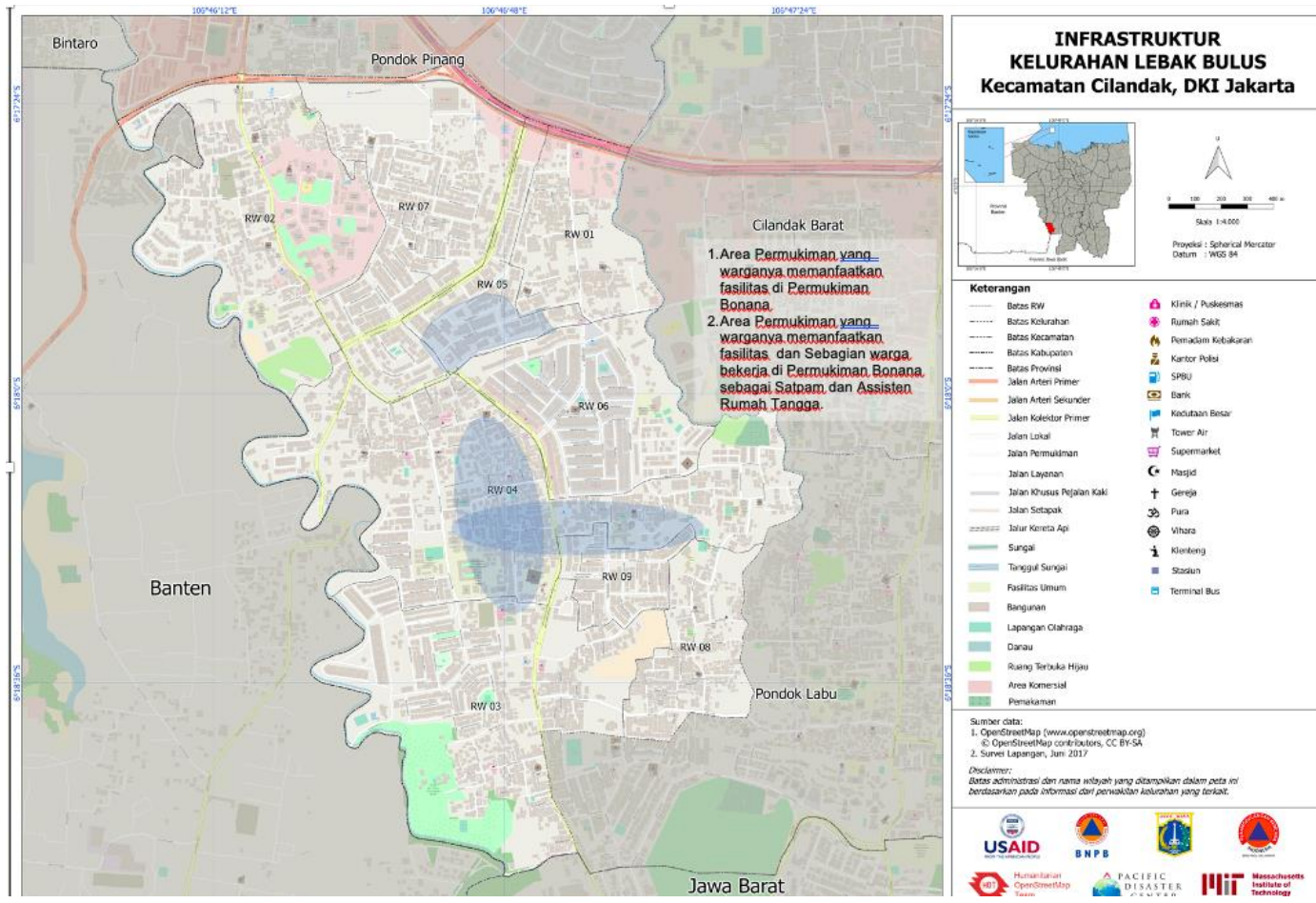

Gambar 5. Lokasi Perukiman Warga di Luar Permukiman Bonana yang memiliki hubungan Sosial

Sumber: di olah Kembali peneliti, dengan sumber gambar/peta: https://drive.google.com/file/d/10CuWrvcrGM_IGKTKTP5GbpkgEuRKaBoj/view 
Kegiatan warga lainnya dengan koordinasi pengurus RW 06 antara lain: Sunday Market yang merupakan bazar yakni salah satu acara untuk memperingati hari raya kemerdekaan 17 Agustus. Pada saat 17 Agustus dilakukan juga upacara bendera, dilanjutkan dengan perlombaan yang dikuti warga Permukiman Bonana. Bazar dengan tema Sunday Market ini, diadakan juga saat memperingati hari sumpah pemuda, seluruh kegiatan Bazar diikuti oleh warga Bonana, yang membuka lapak hasil kerajinan, makanan hingga makanan. Kunjungan untuk kaum Dhuafa, juga menjadi salah satu kegiatan yang dilakukan oleh pengurus RW 06.

Lapangan basket memiliki multi fungsi, seperti untuk kegiatan senam Lansia, upacara-upacara hari nasional, sebagai tempat untuk bazar. Penggunaan lapangan basket yang multifungsi digunakan dengan berbagai kegiatan diatur dengan jadwal yang dilakukan secara bergilir. Untuk Senam Lansia, dilakukan pada hari minggu dari pukul 6.00 hingga pukul 8.00. Setelah itu digunakan untuk berlatih basket usia anak-anak. Selain hari minggu lapangan basket ini digunakan untuk bermain Futsal atau Basket oleh anak remaja dan dewasa. Pengguna lapangan basket dan badminton yang ada pada ruang publik ini selain warga Permukiman Bonana juga masyarakat luar, terkadang lapangan basket dimanfaatkan sekolah yang ada di sekitar Kelurahan Lebak Bulus.

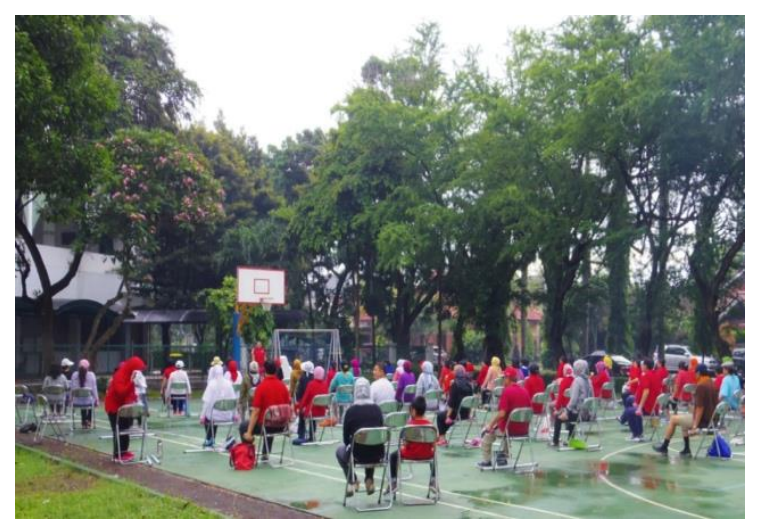

A:Senam untuk Lansia

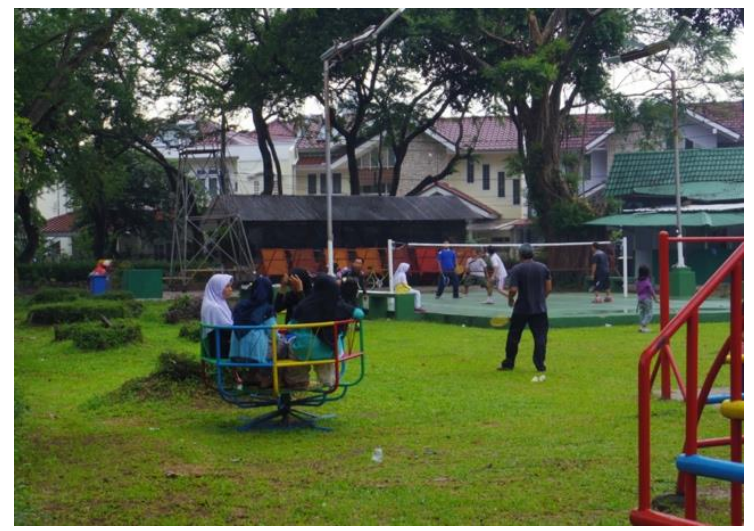

C:Tempat Bermain anak

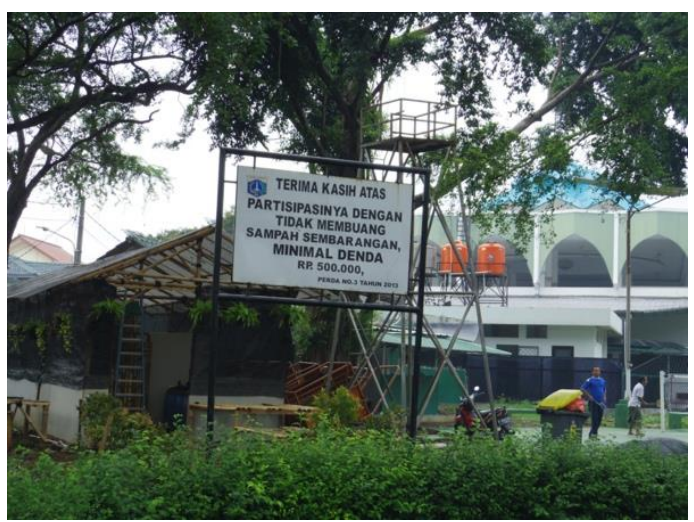

B:Tempat Pembuatan Kompos

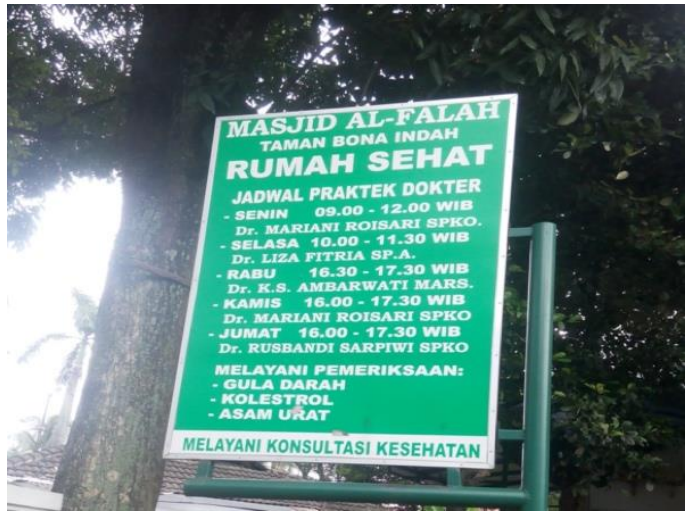

D: Pengobatan Umum Untuk Masyarakat

Gambar 6. Aktivitas Warga Di Lingkungan Permukiman Bonana

Kegiatan lain yang terkait dengan olah raga, adalah futsal, basket dan senam altetic dan Bulu Tangkis. Kegiatan ini diselenggarakan di Ruang Terbuka Publik yang lokasinya berada pada pusat Permukiman Bonana. Kegiatan olah raga ini dilakukan secara rutin dan akhirnya, membentuk komunitas, demikan juga Jalan Pagi. Karena kerap bertemu saat jalan pagi, akhirnya mereka selalu 
melakukan secara bersama, dan melakukan pertemuan informal. Kegiatan warga Permukiman Bonana, yang dilakukan secara bersama dan terus menerus, merupakan sebuah interaksi, yang dapat membentuk sebuah komunitas yang menjadikan Permukiman layak huni (livable).

Kelangsungan hidup masyarakat mengacu pada kualitas lingkungan dan sosial dari suatu daerah seperti yang dirasakan oleh penduduk, karyawan, pelanggan, dan pengunjung. Ini adalah jumlah faktor yang menambah kualitas kehidupan masyarakat termasuk lingkungan yang dibangun dan alami (Flint, 2013).

Kaum dhuafa bagi warga Permukiman Bonana, adalah mereka yang hidup dengan mata pencaharian sebagai Pemulung, yang memang banyak berlalu lalang di dalam Permukiman Bonana, dan tempat tinggal mereka tidak jauh dari Permukiman Bonana $(<1 \mathrm{~km})$. Mereka yang menjadi target saat Idul Fitri untuk mendapatkan zakat fitrah yag diserahkan oleh warga Permukiman Bonana, demikian juga saat hari raya Idul Adha, di mana warga Permukiman Bonana berkorban.

Senam Osteoporosis, yang digagas oleh warga dan ditindak lanjuti oleh pengurus RW, diikuti oleh lansia dengan menggunakan instruktur seorang dokter. Kegiatan diselengarakan pada hari minggu pagi pukul 6.00-8.00. Peserta senam dikuti oleh warga, dan masyarakat di luar Bonana, senam diselenggarakan di Lapangan Basket. Kegiatan lain yang di bawah koordinasi RW adalah kegiatan Penangulangan Sarang Nyamuk (PSN). Dibentuk kader jumantik pada tiap RT dilingkungan RW 06. Juru Pemantau Jentik (Jumantik) adalah anggota masyarakat yang secara sukarela memantau keberadaan jentik nyamuk Aedes aegypti di lingkungan RW 06. Mereka memiliki tanggung jawab untuk mendorong masyarakat melakukan Pemberantasan Sarang Nyamuk (PSN) secara rutin.

Warga dengan Masyarakat Luar tersebut. Di samping adanya rumah sehat di lingkungan Masjid Alfalah yang dapat dimanfaatkan oleh masyarakat luar Permukiman Bonana juga sebagai media interaksi, demikian juga kunjungan ke para Duafa dilingkungan Permukiman Bonana, dan pembagian zakat fitrah dan hewan kurban oleh Masjid Alfalah mendekatkan warga Permukiman Bonana dengan masyarakat luar. Interaksi yang baik terbangun atas hubungan sosial atau interaksi warga Permukiman Bonana, yang dominan atau kuat, dan kelembagaan yang terorganisir baik.

"Istilah lingkungan dan masyarakat mengacu pada konsep yang berbeda. Sebuah lingkungan dapat didefinisikan sebagai lingkungan sosiospasial mana hubungan utama di antara penduduk mendominasi. Jika hubungan keintiman ini, atau hubungan utama, tidak ada, seperti kemungkinan tinggal di blok permukiman kota besar, di mana penghuni apartemen memiliki sedikit hubungan dengan satu sama lain, kita hampir tidak bisa menyebut pengaturan seperti itu "lingkungan." Sebaliknya, konsep komunitas sering disediakan untuk kolektivitas spasial dengan komponen kelembagaan. Artinya, ini dapat didefinisikan sebagai lingkungan sosio spasial yang memiliki lembaga sosial terorganisir yang khusus menangani masalah lokal. Pendekatan sosiospatial bahwa lingkungan spasial memainkan peran penting dalam interaksi manusia, (Mark Gottdiener \& Ray Hutchison, 2011)”.

\section{Kebersihan/ Keindahan dan Partispasi Warga}

Pengelolaan kebersihan Permukiman dilakukan secara mandiri, di bawah koordinasi pengurus RW, belum mendapat bantuan dari pemerintah. Permukiman Bonana mempunyai tenaga penyapu jalan berjumlah 10 orang, dengan didominasi oleh wanita. Pemeliharaan Taman didalam Permukiman Bonana dilakukan oleh pekerja berjumlah 4 oarang, sedangkan pengangkutan sampah domestik (rumah tangga dilakukan dengan truk yang disewa dengan pembayaran per bulan berikut crew pengumpul sampah. Kebersihan dan keindahan tidak terbatas pada pembuangan 
sampah domestik, tetapi juga pohon dan rumput. Rumput yang panjang dan liar, serta pohon yang rentan patah dan menggangu jalan juga perlu dipangkas. Pemangkasan dan pemotongan rumput dilakukan oleh anggota satpam. Pada saat libur hari raya Idul Fitri, petugas kebersihan yang meliputi penyapu jalan dan pengangkut sampah libur, maka sampah didalam Permukiman menumpuk,sehingga menimbulkan pemandangan yang tidak menarik. Akibat liburnya petugas kebersihan, kita dapat melihat adanya ketergantungan warga Permukiman Bonana pada petugas kebersihan seperti yang diuraikan pada ekosistem Sosial, ada nya saling ketegantungan (interdependency) di dalam masyarakat.

Pembiayaan keamanan dan kebersihan ini oleh warga, dengan tiga (3) cara, yaitu:1) melalui iuran bulanan yang diambil dari seluruh warga, 2) Penjualan pupuk kompos, 3) donatur. Khusus donator seperti sudah dibahas di awal untuk pembelian truk sampah, dan hal sumbangan lannya adalah untuk memperbaki fasilitas bermain anak dan perbaikan Lapangan Basket serta membiayai perawatan Ruang Terbuka Hijau/taman.

\section{KESIMPULAN}

Kegiatan yang dilakukan warga Permukiman Bonana, tidak saja dilakukan oleh pengurus RW 06, tapi dilakukan juga oleh pengurus Mesjid Bonana seperti kegiatan yang terkait acara keagamaan, dan kesehatan, hal ini diwujudkan dengan membuka Rumah Sehat yang dimanfaatkan oleh warga dari dalam dan juga luar Permukiman Bonana yang tidak mampu. Kerja sama antara warga dengan pengurus Rukun Warga, sebagai upaya terpeliharanya lingkungan yang nyaman dan aman di mana mereka tinggal.

Kegiatan Sunday Maket yang dilakukan menjelang hari raya idul fitri, dan hari besar Nasional, maupun perayaan 17 Agustus, kegiatan olah raga bagi lansia berupa senam ostoposis, dan senam pernafasan, dengan peserta dari warga Permukiman Bonana dan warga luar, dengan menggunakan, seluruh kegiatan ini difasilitasi oleh warga dengan menggunakan pelatih dari luar warga Permukiman Bonana.

Keamanan dan kebersihan Permukiman Bonana, didukung Partisipasi warga terlihat dengan keterlibatan warga pada pemeliharaan kebersihan lingkungan dengan cara membayar iuran maupum menjadi donor untuk keamanan dan kebersihan, pembuatan pupuk kompos, dan juru pemantau jentik (Jumantik) dilakukan anggota masyarakat yang secara sukarela memantau keberadaan jentik nyamuk Aedes aegypti.

Ruang terbuka publik yang yang ada pada Permukiman Bonana merupakan tempat berinteraksi antara warga Bonana, maupun antar warga bonana dengan masyarakat luar

\section{Ucapan Terima Kasih}

Penulis mengucapakan terima kasih kepada bapak ketua Rukun Warga Permukiman Bonana, Satpam, pedagang makananan maupun sayur, ibu/bapak aktivis yang terlibat secara aktif pada penanganan kebersihan, seperti adanya tempat pembuatan kompos, dan ibu-ibu yang yang terlibat penamganan Jentik.

Penulis juga mengucapakan terima kasih kepada Lembaga Penelitian dan Pengabdiaan Masayarakat (LPPM) Untar yang telah mendanai penelitian. Penulis terima kasih Dekan Fakultas Teknik, dan Kaprodi dan teman-teman dosen di lingkungan Program Studi Perencanaan Wilayah dan Kota yang mendukung penelitiaan ini secara moral. 


\section{REFERENSI}

Altman \& Wandersman, E., (1987). Neighborhood and Community Environments. Springer Science+Business Media New York Originally published by Plenum Press, New York in 1987.

Ahlbrandt, S. R. (1984). Neighborhoods,People, and Community. New York and London: Plenum Press.

Flint. R. W.(2013). Practice of Sustainable Community Development A Participatory Framework for Change. New York: Springer Science+Business Media.

Gottdiener.M, Hutchison. R (2011) The new urban sociology, 4th ed. Philadelphia: Westview Press.

Girling. C, Kellett. R. (2005). Skinny Streets and Green Neighborhoods. Washington DC: Island Press.

Flanagan, W. G. (2010).Urban sociology : images and structure.5th ed. Lanham, Maryland: Rowman \& Littlefield Publishers, Inc.P:350

Homoud. M.A \& Tassinary.L.G, (2004). Social interactions at the neighborhood-level as a function of external space enclosure. https://www.researchgate.net/publication

Hidayat, I.W. (2010). The Ecological Role Of Trees and Their Interactions in Forming The Micro Climate Amenities of Environment. Jurnal Bumi Lestari volume 19, halaman 182-190. file:///C: \& http://ojs.unud.ac.id/

Mamaghani. N.K. Asadollahi. A.P., Mortezaei. S.R (2015). Designing for Improving Social Relationship with Interaction Design Approach. Asian Conference on Environment-Behaviour Studies. Procedia-Social and Behavioral Sciences. https://www.sciencedirect.com.

Omar.D., Ibrahim. F.I.,Nik Muhamad.N.H (2015). Human Interaction In Open Spaces. Asian Conference On Environment-behavior Studies. Procedia-Social and Behavioral Sciences. https://www.sciencedirect.com.

Park.E, Bugess.W.(1921). Introduction To The Sciences of Sociology. Chicago: University of Chicago Press.

Robertson.D., Smyth.J., and McIntosh.,I. (2008). Neighbourhood identity. Joseph Rowntree Foundation. 11:30:05. http://www.tandfonline.com/doi/abs/1

Rao, R. (1997). An Approach to Open Space Planning Based on the Principles of Landscape Ecology: An Application to Greater Roanoke Area. Thesis submitted to the faculty of the Virginia Polytechnic Institute and State University in partial fulfillment of the requirements for the degree of Master of Landscape Architecture. https://theses.lib.vt.edu/

Rode, P., and Burdett. (2011) Cities: investing in energy and resource efficiency. Towards a green economy: pathways to sustainable development and poverty eradication. United Nations Environment Programme, pp.453-492. $\quad$ ISBN 9789280731439. <http://www.unep.org/greeneconomy/greeneconomyreport

Schwirian. K.P.(1983). Models Of Neighborhood Change.Annual Review of Sosiology, Volume 9.(1983).pp 83-102. http://www.annualreviews.org/doi/abs/.

Siegmunt. O. (2016). Neighborhood Disorganization and Social Control. New York: Springer.

Srinivas. H (2003). The Ecosystem Approach to Urban Environmental Management, Operationalizing the Cities as Sustainable Ecosystems (CASE) Initiative. http:/unep.or.jp/ietc/Focus/eco.pdf.

Soeriaatmadja, R.E. (1989). Ilmu Lingkungan, edisi keempat. Bandung: ITB.

Webster. A. (1990). Introduction to the Sociology of Development.second edition. New York PALCRAVE Houndmills, Basingstoke, Hampshire RC21 6XS and 175 Fifth Avenue, New York, N.Y. 10010. Transferred to digital printing 2002.

Zabel. (2007). Street Trees: A New Hampshire Primer. Benefits and Implementation Considerations. Rockefeller Center at Dartmouth College Policy Research Shop A Center for Public Policy and the Social Sciences.<http://policyresearch.dartmouth.edu $>$ 